\title{
Effect of Feed Restriction on Broiler Chicks Prior to Slaughter
}

\author{
Nadir Abdelraheem 1,2,3*, Magdi Mohammed Mohammed Ahmed ${ }^{2,4}$, Fujiang Hou ${ }^{3}$ \\ ${ }^{1}$ Department of Animal Production, Faculty of Agriculture, Red Sea University, Portsudan, Sudan \\ ${ }^{2}$ Department of Animal Production, Environment and Natural Resources and Desertification Research Institute, National Center \\ for Research, Khartoum, Sudan \\ ${ }^{3}$ State Key Laboratory of Grassland Agro-Ecosystems, College of Pastoral Agriculture Science and Technology, Lanzhou \\ University, Lanzhou, China \\ ${ }^{4}$ Alsafar for Eggs Production Project, Omdurman, Sudan \\ Email: *nadir.hssn@gmail.com
}

How to cite this paper: Abdelraheem, N., Ahmed, M.M.M. and Hou, F.J. (2019) Effect of Feed Restriction on Broiler Chicks Prior to Slaughter. Open Journal of Animal Sciences, 9, 12-22.

https://doi.org/10.4236/ojas.2019.91002

Received: June 26, 2018

Accepted: December 17, 2018

Published: December 20, 2018

Copyright (c) 2019 by authors and Scientific Research Publishing Inc. This work is licensed under the Creative Commons Attribution International License (CC BY 4.0)

http://creativecommons.org/licenses/by/4.0/

\begin{abstract}
The present study was conducted to study the effect of feed restriction prior to slaughter on carcass weight of male broiler chicks from 32 to 40 days of age. A total number of 180 (Pure line) male broiler chicks were taken randomly, labeled and divided into six groups. At 32 days of age, the experimental groups were put under the experimental feeding program. Group A fed ad libitum (control) while group B and C fed 120, $60 \mathrm{gm} / \mathrm{bird} /$ day for eight days, respectively. Group D and E fed 120, $60 \mathrm{gm} / \mathrm{bird} /$ day for four days respectively, followed by zero feeding for an extra 4 days. Group F deprived of food during the whole experimental period ( 8 days). The experimental diet was formulated to be approximately iso caloric-iso nitrogenous containing sorghum, groundnut cake, broiler concentrate, calcium, salt, lysine, methionine, and premix. The parameters taken were live body weight, feed intake, mortality, carcass, and non-carcass values. The effect of feed restriction program on male broiler chicks was not significant during the period from 32 to 34 days of age for parameters final live body weight, carcass weight, and dressing percentage, but net weight (gain or loss) was affected by feed restriction program and showed a significant difference $(\mathrm{P}<0.01)$ between experimental groups. From 32 to 36 days of age male broilers subjected to feed restriction regimes showed the lowest reading for final live body weight, net weight (gain or loss) and carcass weight and the difference were significant $(\mathrm{P}<0.01)$. There was no significant difference $(P>0.05)$ between experimental groups for dressing percentage during period from 32 to 36 days of age. At the period from 32 to 38 days and the period from 32 to 40 days of age, all parameters were significantly affected by feed restriction program. It was concluded that carcass weight of broiler chickens can be controlled using different options of
\end{abstract}


feed restriction programs according to the need of the market and the producer situation with special consideration to the economic return.

\section{Keywords}

Feed Restriction, Prior to Slaughter, Broiler, Carcass Weight

\section{Introduction}

The poultry meat production has become one of the most dynamic areas of animal production. Poultry meat is considered as a healthy and nutritious among the available meat sources.

The poultry industry in Sudan was largely expanded and improved during the few last years, both in size of production and techniques. There is a great shift from traditional methods (opened system of rearing) to a modern one (closed system). This shift has been reflected both in production and productivity.

Producers prefer to have a broiler house size of about 25 - 30 thousand birds as a reliable size, leading to slaughter the birds per house into several days.

One of the major problems that facing broiler meat marketing is the increased carcass weight of birds above 1100 - $1200 \mathrm{~g}$ (the marketable weight in Sudan).

Generally, when birds eat more, they tend to have a greater body weight at market age. The improvement noted in market body weight has been attained due to increased feed consumption, which is related to genetics [1] and supported by nutrition.

Nutrition has been found to play an important role in controlling some problems and improving broiler performance, also feeding factors have a considerable impact on carcass composition of broiler chickens [2].

Feeding accounts about $70 \%$ of the cost of production, which can sometimes rise up to $80 \%$ [3] [4] and this high cost created the need to improve the efficiency of feed utilization.

This experiment was designed to implement feed restriction programs in order to control the increase of carcass weight to be within the preferable market weight (1100 - $1200 \mathrm{~g} / \mathrm{bird})$ and to determine the economic impact of these programs.

\section{Materials and Methods}

The experiment runs in this study was conducted in the Sudanese Kwaiti Company Farm at AL-Bagair Village which lies about $25 \mathrm{~km}$ southern to the Capital Khartoum.

\subsection{Rearing Phase}

A total number of four hundred day-old unsexed broiler chicks of Pure Line Strain were obtained from INMAA local hatchery. The birds were reared using 
deep litter of wood shavings in a closed-side poultry house from day-old to the end point set for slaughter. Throughout the experimental period light was provided for $24 \mathrm{hrs}$

\subsection{Experimental Diets}

The experimental diets were formulated to be approximately iso caloric ( 3.2 $\mathrm{kcal} / \mathrm{kg}$ and iso nitrogenous (22.5\%).

The chicks were fed the pre-starter diet from day-old to seven days of age before being shifted to the starter diet from 8 to 17 days of age. They were then fed the grower diet from 18 - 35 days of age and the finisher diet from 36 days of age to the end of the experimental feeding. The percent inclusion rate of ingredients of the pre-starter, starter, grower and finisher diets were shown in Table 1 while their percent chemical composition as shown in Table 2. The experimental birds were offered feed and water in a sufficient number of feeders and drinkers. The birds have ad libitum feed and water.

Feed samples were analyzed according to the methods of AOAC [5].

At 29 days of age 180 male birds were chosen randomly, labeled and divided into six groups each group contains 30 birds. The experimental birds were allowed to have a period of three days as adaptation period before the onset of the experiment (at 32 days of age).

\subsection{Restriction Phase}

At 32 days of age, treatment was beginning into six groups. Group A fed ad libitum (control) while group B and C fed $120 \mathrm{~g}, 60 \mathrm{~g} / \mathrm{bird} /$ day for eight days, respectively. Group D and E fed $120 \mathrm{~g}, 60 \mathrm{~g} / \mathrm{bird} /$ day for four days, respectively followed by zero feeding. Group F deprived of food during the whole experimental period (8 days).

\subsection{Data Collected}

Day-old birds at the rearing phase were weighed using a balance of maximum 5 $\mathrm{kg}$. Live body weight and feed intake were taken every week, but during restriction phase birds were weighed individually every $48 \mathrm{hrs}$. Mortality during both phases was recorded daily as it occurs.

Table 1. Percent inclusion rates (fresh weight basis) of ingredients used in the experimental rations.

\begin{tabular}{ccccc}
\hline & \multicolumn{3}{c}{ Percent inclusion rate } \\
\cline { 2 - 5 } Ingredients & Pre-starter & Starter & Grower & Finisher \\
\hline Sorghum & & 62 & 68 & 72 \\
Groundnut cake & Closed formula & 32 & 26 & 22 \\
Limestone & 1 & 1 & 1 \\
Concentrate & 5 & 5 & 5 \\
\hline
\end{tabular}

Note: Pre-starter diet form day old to seven days of age, Starter: from 8 to 17 days, Grower: 18 - 35 days, Finisher: from 36 days of age to the end of the experimental according to feeding system of Sudanese Kwaiti Company Farm. 
Table 2. Analysed percent chemical composition (dry matter basis) of the diets used in the experiment.

\begin{tabular}{ccccc}
\hline \multirow{2}{*}{ Component } & \multicolumn{4}{c}{ Experimental Diets } \\
\cline { 2 - 5 } & Pre-starter & Starter & Grower & Finisher \\
\hline Dry matter & 92.4 & 94 & 93.9 & 94.3 \\
Crude protein & 22.5 & 22.2 & 22.4 & 22.8 \\
Ether extract & 6.7 & 4.8 & 3.6 & 4.3 \\
Crude fiber & 3.5 & 4.3 & 4.4 & 4.8 \\
Nitrogen-free extract & 53.8 & 56.9 & 57.3 & 56.1 \\
Ash & 5.9 & 5.8 & 6.2 & 6.3 \\
ME (Kcal/Kg) & 3234 & 3206 & 3143 & 3154 \\
Calcium & 0.605 & 0.620 & 0.625 & 0.655 \\
Phosphorous & 0.145 & 0.150 & 0.125 & 0.160 \\
\hline
\end{tabular}

Metabolizable energy values were calculated by the modified equation of Lodhi et al. [7].

\subsection{Slaughter Procedure and Slaughter Data}

At 34 days of age, every $48 \mathrm{hrs}$ all birds of each group were weighed. Then four birds from each group were randomly selected to slaughtering. Slaughtering was done according to Islamic Shariah by severing right and left jugular and carotid cervical vessels just caudal to the larynx using a sharp knife. After complete bleeding, the head at its articulation and shanks at the hock joint were separated and weighed. The birds were then plucked after soaking in warm water. Evisceration was done by ventral medial incision. Liver and gizzard organs were separated and weighed. Carcasses were finally weighed, soaked in ice water and sealed in polythene bags.

\subsection{Statistical Analyses}

Completely Randomized Design (CRD) was used in this experiment, and the difference between the groups for all parameters was determined by analyses of variance (ANOVA) according to Gomez and Gomez [6]. The coefficient of Variation (C.V) was calculated from the ANOVA table following the formula:

$$
\text { C.V }=\frac{\sqrt{\text { Residual.m.s }}}{\text { overall mean }} \times 100
$$

\section{Results and Discussion}

The present study was conducted to study the effect of feed restriction prior to slaughter on carcass weight of male broiler chicks 32 to 40 days of age.

\subsection{Performance of Male Broiler Chicks 32 to 34 Days of Age}

As Table 3 shown final live body weight was not significantly $(\mathrm{P}>0.05)$ different between experimental groups during period 32 to 34 days of age. This indicated 
Table 3. Analysis of variance and average (mean \pm s.d) performance values of male broiler chicks subjected to feed restriction prior to slaughter at $32-34$ days of age.

\begin{tabular}{|c|c|c|c|c|c|c|c|c|}
\hline \multirow{2}{*}{ Item } & \multicolumn{6}{|c|}{ Groups } & \multirow{2}{*}{ L.S } & \multirow{2}{*}{ C.V } \\
\hline & A & B & $\mathrm{C}$ & $\mathrm{D}$ & $\mathrm{E}$ & $\mathrm{F}$ & & \\
\hline No. of chick & 30 & 30 & 30 & 30 & 30 & 30 & & \\
\hline Mortality & 0 & 0 & 0 & 0 & 0 & 0 & & \\
\hline $\begin{array}{l}\text { Initial restriction live weight } \\
\text { (g/bird) }\end{array}$ & $1475 \pm 135$ & $1489 \pm 150$ & $1369 \pm 194$ & $1408 \pm 147$ & $1460 \pm 236$ & $1420 \pm 314$ & NS & 14.3 \\
\hline Final live weight $\mathrm{g} /$ bird & $1639 \pm 131$ & $1648 \pm 162$ & $1361 \pm 208$ & $1498 \pm 120$ & $1439 \pm 209$ & $1283 \pm 276$ & NS & 12.98 \\
\hline Feed intake g/bird/day during & (adlib) & Restricted & Restricted & Restricted & Restricted & Restricted & & \\
\hline the exp. period (2 days) & 150 & 120 & 60 & 120 & 60 & 0 & & \\
\hline Weight gain (g/bird) & $+164^{\mathrm{a}} \pm 11$ & $+159^{\mathrm{a}} \pm 55$ & $-8^{c} \pm 36$ & $+90^{\mathrm{b}} \pm 64$ & $-21^{c} \pm 41$ & $-138^{\mathrm{d}} \pm 39$ & ** & 12.99 \\
\hline Carcass weight (g/bird) & $1185 \pm 122$ & $1191 \pm 113$ & $1023 \pm 173$ & $1108 \pm 84$ & $1061 \pm 174$ & $976 \pm 220$ & NS & 14.2 \\
\hline Dressing \% & $72 \pm 3$ & $72 \pm 3$ & $75 \pm 1$ & $74 \pm 1$ & $74 \pm 2$ & $76 \pm 2$ & NS & 2.7 \\
\hline
\end{tabular}

*: P < 0.05, **: P $<0.01$, NS: Not Significant; Means in a row with the same letter designation are not significantly (P > 0.05) different; L.S: Level of Significant; C.V: Coefficient of Variation.

that the experimental birds were not affected statistically by feed restriction program during this period. But numerically the more sever feed restricted groups (C, E, and F) shows the lowest reading for final live weight. This finding previously was reported by Abdul and Friani [8] who showed lower body weight at 21 - 35 days of age in restricted birds allowed $75 \%$ and $60 \%$ of ad libitum intake.

Weight gain was significantly $(\mathrm{P}<0.01)$ different among the experimental groups. Group B and D gained less than control group while groups C, E and F showed a loss in weight. This decrease in weight gain could be due to decreased feed intake of these groups, and also may be due to the evacuation of the gastrointestinal tract. This result is in line with Ismail [9] who reported that feed restriction subject the birds to a period of undernutrition, due to reduced intake of nutrients, which results in slow growth and loss of body weight. Many previous studies found that broilers kept under a restricted feeding program gained less weight than those kept under ad libitum feeding [4] [10] [11]. In the same period, carcass weight and dressing percentage were not differed significantly $(P>0.05)$. This result may be related to the fact that carcass weight is the reflection of the body weight [12].

\subsection{Performance of Male Broiler Chicks 32 to 36 Days of Age}

Effect of feed restriction program on the performance of male broiler chicks from 32 to 36 days of age is shown in Table 4. Feed restriction created a significant effect in the final live weight of experimental groups. Control group showed the highest value for final live weight $(1808 \pm 253 \mathrm{~g})$ and group $\mathrm{F}$ that subjected to a longer period of feed removal showed the lowest value (1208 $\pm 124 \mathrm{~g}$ ), which supports the statement that improvement in body weight of birds is highly correlated to feed consumption and duration of feed Restriction [9] [13]-[18]. 
Table 4. Analysis of variance and average (mean \pm s.d) performance values of male broiler chicks subjected to feed restriction prior to slaughter at $32-36$ days of age.

\begin{tabular}{|c|c|c|c|c|c|c|c|c|}
\hline \multirow{2}{*}{ Item } & \multicolumn{6}{|c|}{ Groups } & \multirow{2}{*}{ L.S } & \multirow{2}{*}{ C.V } \\
\hline & A & B & C & $\mathrm{D}$ & $\mathrm{E}$ & $\mathrm{F}$ & & \\
\hline No. of chick & 30 & 30 & 30 & 30 & 30 & 30 & & \\
\hline Mortality & 0 & 0 & 0 & 0 & 0 & 0 & & \\
\hline $\begin{array}{l}\text { Initial restriction live weight } \\
\text { (g/bird) }\end{array}$ & $1459 \pm 202$ & $1428 \pm 242$ & $1379 \pm 90$ & $1351 \pm 196$ & $1368 \pm 164$ & $1339 \pm 160$ & NS & 13.10 \\
\hline Final live weight (g/bird) & $1808^{\mathrm{a}} \pm 253$ & $1653^{\mathrm{ab}} \pm 286$ & $1404^{\mathrm{bc}} \pm 110$ & $1529^{\mathrm{ab}} \pm 224$ & $1405^{\mathrm{bc}} \pm 122$ & $1208^{\mathrm{c}} \pm 124$ & $* *$ & 13.28 \\
\hline $\begin{array}{l}\text { Feed intake g/bird/day during } \\
\text { the exp. period ( } 4 \text { days) }\end{array}$ & $\begin{array}{l}\text { (adlib) } \\
162\end{array}$ & $\begin{array}{l}\text { Restricted } \\
120\end{array}$ & $\begin{array}{l}\text { Restricted } \\
\quad 60\end{array}$ & $\begin{array}{c}\text { Restricted } \\
120\end{array}$ & $\begin{array}{c}\text { Restricted } \\
60\end{array}$ & $\begin{array}{c}\text { Restricted } \\
0\end{array}$ & & \\
\hline Weight gain (g/bird) & $+349^{a} \pm 65$ & $+225^{\mathrm{b}} \pm 51$ & $+25^{c} \pm 23$ & $+178^{\mathrm{b}} \pm 33$ & $+38^{c} \pm 45$ & $-131^{\mathrm{d}} \pm 66$ & $* *$ & 12.21 \\
\hline Carcass weight (g/bird) & $1338^{\mathrm{a}} \pm 194$ & $1244^{\mathrm{ab}} \pm 212$ & $1029^{b c} \pm 86$ & $1123^{\mathrm{ab}} \pm 175$ & $1046^{\mathrm{bc}} \pm 105$ & $879^{c} \pm 113$ & $* *$ & 14.0 \\
\hline Dressing \% & $74 \pm 2$ & $75 \pm 1$ & $73 \pm 1$ & $73 \pm 1$ & $74 \pm 1$ & $72 \pm 4$ & NS & 2.6 \\
\hline
\end{tabular}

*: P < 0.05, **: P < 0.01, NS: Not Significant; Means in a row with the same letter designation are not significantly (P > 0.05) different; L.S: Level of Significant; C.V: Coefficient of Variation.

During the same period carcass weight was significantly $(\mathrm{P}<0.01)$ lower in restricted groups than that fed ad libitum. This finding was expected because carcass weight depends on live weight as stated by Kokoszynski and Bernacki [19].

The dressing percentage was not significantly $(\mathrm{P}>0.05)$ different between the experimental groups and ranged from $72 \%$ for group $\mathrm{F}$ to $75 \%$ for group $\mathrm{B}$. The same range of dressing percentage was achieved by Janocha et al. [20].

\subsection{Performance of Male Broiler Chicks 32 to 38 Days of Age}

During the period 32 to 38 day of age, the control group was highest for final live weight, weight gain, and carcass weight, while other groups showed the lowest values than control (Table 5). The probable explanation of the lower values of the feed-restricted groups is that with an increase of birds age, the effect of feed restriction program will be more severe. This result agreed with Santoso et al. [21] who restricted broilers to $75 \%, 65 \%, 55 \%$ and $45 \%$ of ad libitum intake for 10 days and found that body weight of severely restricted (65\% or less) male and female broiler chicken was significantly lower than ad libitum fed birds at 42 days.

The dressing percentage was also significantly $(\mathrm{P}<0.05)$ different between groups in an irregular pattern. This may be due to fact that birds of similar weight may not always yield the same amount of edible carcass [22].

\subsection{Performance of Male Broiler Chicks 32 to 40 Days of Age}

Table 6 shows the performance of male broiler chicks 32 to 40 days of age. Group A was superior for final live weight, weight gain, carcass weight and dressing percentage followed by group B while group F showed the lowest value 
Table 5. Analysis of variance and average (mean \pm s.d) performance values of male broiler chicks subjected to feed restriction prior to slaughter at $32-38$ days of age.

\begin{tabular}{|c|c|c|c|c|c|c|c|c|}
\hline \multirow{2}{*}{ Item } & \multicolumn{6}{|c|}{ Groups } & \multirow{2}{*}{ L.S } & \multirow{2}{*}{ C.V } \\
\hline & A & B & $\mathrm{C}$ & $\mathrm{D}$ & $\mathrm{E}$ & $\mathrm{F}$ & & \\
\hline No. of chick & 30 & 30 & 30 & 30 & 30 & 30 & & \\
\hline Mortality & 0 & 0 & 0 & 0 & 0 & 0 & & \\
\hline $\begin{array}{l}\text { Initial restriction live weight } \\
\text { (g/bird) }\end{array}$ & $1571^{a} \pm 60$ & $1450^{a} \pm 157$ & $1436^{\mathrm{ab}} \pm 102$ & $1568^{\mathrm{a}} \pm 151$ & $1439^{\mathrm{ab}} \pm 65$ & $1256^{\mathrm{b}} \pm 107$ & * & 8.7 \\
\hline Final live weight (g/bird) & $2176^{\mathrm{a}} \pm 104$ & $1815^{\mathrm{bc}} \pm 54$ & $1529^{\mathrm{cd}} \pm 144$ & $1673^{\mathrm{bc}} \pm 182$ & $1353^{\mathrm{de}} \pm 82$ & $1144^{\mathrm{e}} \pm 114$ & ** & 8.8 \\
\hline $\begin{array}{l}\text { Feed intake g/bird/day during } \\
\text { the exp. period ( } 6 \text { days) }\end{array}$ & $\begin{array}{c}\text { (adlib) } \\
165\end{array}$ & $\begin{array}{l}\text { Restricted } \\
120\end{array}$ & $\begin{array}{c}\text { Restricted } \\
60\end{array}$ & $\begin{array}{c}\text { Restricted } \\
0\end{array}$ & $\begin{array}{c}\text { Restricted } \\
0\end{array}$ & $\begin{array}{c}\text { Restricted } \\
0\end{array}$ & & \\
\hline Weight gain (g/bird) & $+605^{a} \pm 97$ & $+365^{\mathrm{b}} \pm 44$ & $+93^{c} \pm 42$ & $+105^{\mathrm{c}} \pm 33$ & $-86^{\mathrm{d}} \pm 29$ & $-113^{\mathrm{d}} \pm 25$ & $* *$ & 11.09 \\
\hline Carcass weight (g/bird) & $1563^{\mathrm{a}} \pm 117$ & $1351^{\mathrm{b}} \pm 136$ & $1106^{\mathrm{cd}} \pm 128$ & $1243^{\mathrm{bc}} \pm 122$ & $1011^{\mathrm{d}} \pm 62$ & $813^{\mathrm{e}} \pm 85$ & $* *$ & 9.4 \\
\hline Dressing \% & $72^{c} \pm 1$ & $74^{\mathrm{ab}} \pm 1$ & $72^{\mathrm{bc}} \pm 2$ & $74^{\mathrm{ab}} \pm 2$ & $75^{\mathrm{a}} \pm 2$ & $71^{c} \pm 2$ & * & 2.2 \\
\hline
\end{tabular}

*: P < 0.05, **: P < 0.01, NS: Not Significant; Means in a row with the same letter designation are not significantly (P > 0.05) different; L.S: Level of Significant; C.V: Coefficient of Variation.

Table 6. Analysis of variance and average (mean \pm s.d) performance values of male broiler chicks subjected to feed restriction prior to slaughter at 32 - 40 days of age.

\begin{tabular}{|c|c|c|c|c|c|c|c|c|}
\hline \multirow[b]{2}{*}{ Item } & \multicolumn{6}{|c|}{ Groups } & \multirow{2}{*}{ L.S } & \multirow{2}{*}{ C.V } \\
\hline & A & B & $\mathrm{C}$ & $\mathrm{D}$ & $\mathrm{E}$ & $\mathrm{F}$ & & \\
\hline No. of chick & 30 & 30 & 30 & 30 & 30 & 30 & & \\
\hline Mortality & 0 & 0 & 0 & 0 & 0 & 0 & & \\
\hline $\begin{array}{l}\text { Initial restriction live weight } \\
\text { (g/bird) }\end{array}$ & $1553^{\mathrm{a}} \pm 109$ & $1481^{\mathrm{ab}} \pm 51$ & $1188^{c} \pm 102$ & $1398^{\mathrm{b}} \pm 125$ & $1399^{\mathrm{b}} \pm 65$ & $1349^{\mathrm{b}} \pm 128$ & $* *$ & 7.2 \\
\hline Final live weight (g/bird) & $2229^{\mathrm{a}} \pm 134$ & $1939^{\mathrm{b}} \pm 80$ & $1313^{\mathrm{cd}} \pm 124$ & $1408^{\mathrm{c}} \pm 174$ & $1321^{\mathrm{cd}} \pm 74$ & $1161^{\mathrm{d}} \pm 125$ & $* *$ & 7.9 \\
\hline $\begin{array}{l}\text { Feed intake } \mathrm{g} / \mathrm{bird} / \text { day during } \\
\text { the exp. period ( } 8 \text { days) }\end{array}$ & $\begin{array}{c}\text { (adlib) } \\
163\end{array}$ & $\begin{array}{l}\text { Restricted } \\
120\end{array}$ & $\begin{array}{l}\text { Restricted } \\
60\end{array}$ & $\begin{array}{c}\text { Restricted } \\
0\end{array}$ & $\begin{array}{c}\text { Restricted } \\
0\end{array}$ & $\begin{array}{c}\text { Restricted } \\
0\end{array}$ & & \\
\hline Weight gain (g/bird) & $+677^{\mathrm{a}} \pm 106$ & $+458^{\mathrm{b}} \pm 78$ & $+125^{\mathrm{c}} \pm 39$ & $+10^{\mathrm{d}} \pm 74$ & $-78^{\mathrm{d}} \pm 30$ & $-188^{\mathrm{e}} \pm 27$ & $* *$ & 14.1 \\
\hline Carcass weight (g/bird) & $1650^{\mathrm{a}} \pm 106$ & $1413^{\mathrm{b}} \pm 46$ & $956^{\text {cd }} \pm 103$ & $1043^{c} \pm 151$ & $948^{\text {cd }} \pm 58$ & $834^{\mathrm{d}} \pm 100$ & $* *$ & 8.8 \\
\hline Dressing \% & $74^{\mathrm{a}} \pm 1$ & $73^{\mathrm{a}} \pm 1$ & $73^{\mathrm{ab}} \pm 1$ & $74^{\mathrm{a}} \pm 2$ & $72^{\mathrm{b}} \pm 1$ & $72^{\mathrm{b}} \pm 1$ & * & 1.6 \\
\hline
\end{tabular}

${ }^{*}: \mathrm{P}<0.05,{ }^{* *}: \mathrm{P}<0.01, \mathrm{NS}$ : Not Significant; Means in a row with the same letter designation are not significantly $(\mathrm{P}>0.05)$ different. L.S: Level of Significant; C.V: Coefficient of Variation.

for final live weight, loss in weight, carcass weight and dressing percentage. All the previous performance values differ significantly $(\mathrm{P}>0.01)$ among the experimental groups. It is clear that these values vary with feed intake as stated by Urdaneta-Rincon and Leeson [16] and Leeson and Summers [22] that increased feed intake leads to increased live weight, weight gain, and dressing percentage.

This result indicates that the loss in weight increased with increased duration of feed restriction. This agrees with Omosebi et al. [18] who reported that live weight loss increased with the increased duration of feed withdrawal. In our experiment, group $\mathrm{F}$ which was fasted 8 days did not differ significantly from 
groups $\mathrm{C}$ and $\mathrm{E}$. The probable explanation of this result is that birds of group $\mathrm{F}$ who were subjected to severe feed restriction tended to eat litter. Ismail [9] noticed that severely restricted birds ate litter mixed with feed and so they increase their feed intake and reduced feed wastage.

It is generally clear that severe feed restriction will lead to decreased live weight and hence decreased dressing percentage, which can be noticed in that the dressing percentage during the first 4 days of restriction was not significantly different, while in the other 4 days of restriction period was significant, and these findings agreed with Omojola et al. [23] who stated that dressing percentage increases as live weight increase and vice versa.

Effects of feed restriction on non-carcass components were shown in Table 7. With few exceptions, the general trend of increase in the percentage of head, shank, liver, and gizzard when the birds were subjected to severe feed restriction. Omojola et al. [23] reported that edible viscera as a percentage of live weight decrease slightly with increasing body weight. In our study, this was true with the control group. Increase in the percentage of organs when birds subjected to severe feed restriction was due to the decrease live weight of feed restricted birds.

Table 7. Slaughter values (\%) of male broiler chicks subjected to feed restriction prior to slaughter (32 - 40 days of age) represented as \% from the live weight.

\begin{tabular}{|c|c|c|c|c|c|c|c|c|c|}
\hline \multirow{2}{*}{ Item } & \multirow{2}{*}{ Age (days) } & \multicolumn{6}{|c|}{ Groups } & \multirow{2}{*}{ L.S } & \multirow{2}{*}{ C.V } \\
\hline & & A & B & C & $\mathrm{D}$ & $\mathrm{E}$ & $\mathrm{F}$ & & \\
\hline \multirow{4}{*}{ Head } & 32 - 34 days & $3.6^{\mathrm{ab}} \pm 0.2$ & $2.9^{c} \pm 0.2$ & $3.9^{\mathrm{a}} \pm 0.4$ & $3.3^{b c} \pm 0.3$ & $4.1^{\mathrm{a}} \pm 0.4$ & $4.1^{\mathrm{a}}=$ & $* *$ & 11.0 \\
\hline & 32 - 36 days & $3.3 \pm 0.3$ & $2.9 \pm 0.2$ & $3.3 \pm 0.6$ & $3.3 \pm 0.4$ & $3.3 \pm 0.3$ & $3.5=$ & NS & 11.0 \\
\hline & 32 - 38 days & $3.3 \pm 0.3$ & $3.4 \pm 0.2$ & $4.0 \pm 0.4$ & $3.4 \pm 0.4$ & $3.9 \pm 0.7$ & $4.1 \pm 0.4$ & NS & 11.3 \\
\hline & 32 - 40 days & $3.1 \pm 0.3$ & $3.7 \pm 0.2$ & $4.4 \pm 0.1$ & $4.4 \pm 0.6$ & $4.6 \pm 0.2$ & $4.9 \pm 0.3$ & NS & 9.9 \\
\hline \multirow{4}{*}{ Shank } & 32 - 34 days & $4.2^{\text {cd }} \pm 0.2$ & $3.8^{\mathrm{d}} \pm 0.4$ & $4.6^{\mathrm{abc}} \pm 0.2$ & $4.3^{b c} \pm 0.3$ & $5^{a} \pm 0.7$ & $4.8^{\mathrm{ab}} \pm 0.4$ & $* *$ & 9.1 \\
\hline & 32 - 36 days & $4.3^{b c} \pm 0.4$ & $4.3^{c} \pm 0.2$ & $4.9^{\mathrm{a}} \pm 0.4$ & $4.8^{\mathrm{ab}} \pm 0.2$ & $4.6^{\mathrm{ab}} \pm 0.4$ & $5^{a} \pm 0.2$ & * & 6.8 \\
\hline & 32 - 38 days & $4.1^{c} \pm 0.4$ & $5^{\mathrm{b}} \pm 0.4$ & $5.2^{\mathrm{ab}} \pm 0.2$ & $4.9^{\mathrm{b}} \pm 0.3$ & $5.3^{\mathrm{ab}} \pm 0.1$ & $5.5^{\mathrm{a}} \pm 0.5$ & $* *$ & 6.5 \\
\hline & 32 - 40 days & $4.1^{c} \pm 0.1$ & $4.2^{c} \pm 0.2$ & $5.9^{\mathrm{a}} \pm 0.3$ & $5.3^{\mathrm{b}} \pm 0.5$ & $5.8^{\mathrm{a}} \pm 0.3$ & $6^{a} \pm$ & $* *$ & 6.1 \\
\hline \multirow{4}{*}{ Live } & 32 - 34 days & $3.8 \pm 0.5$ & $2.6 \pm 0.2$ & $2.9 \pm 0.3$ & $2.8 \pm 0.2$ & $3.0 \pm 0.7$ & $2.8=$ & NS & 15.9 \\
\hline & 32 - 36 days & $2.7 \pm 0.2$ & $2.4 \pm 0.2$ & $2.5 \pm 0.1$ & $2.6 \pm 0.1$ & $2.6 \pm 0.2$ & $2.8 \pm 0.4$ & NS & 8.8 \\
\hline & 32 - 38 days & $2.9^{\mathrm{a}} \pm 0.1$ & $2.7^{\mathrm{ab}} \pm 0.3$ & $2.6^{\mathrm{bc}} \pm 0.3$ & $2.4^{c} \pm 0.1$ & $2.6^{\mathrm{ab}} \pm 0.2$ & $2.8^{\mathrm{ab}}$ & * & 7.4 \\
\hline & $32-40$ days & $3.0 \pm 0.3$ & $2.8 \pm 0.1$ & $3.1 \pm 0.4$ & $3.2 \pm 0.7$ & $3.3 \pm 0.5$ & $3.7 \pm 0.5$ & NS & 14.3 \\
\hline \multirow{4}{*}{ Gizzard } & 32 - 34 days & $3.0 \pm 0.5$ & $2.0 \pm 0.1$ & $2.6 \pm 0.3$ & $2.4 \pm 0.4$ & $2.7 \pm 0.3$ & $2.7 \pm 0.7$ & NS & 12.4 \\
\hline & 32 - 36 days & $2.1 \pm 0.3$ & $2.1 \pm 0.2$ & $2.5 \pm 0.2$ & $2.5 \pm 0.5$ & $2.4 \pm 0.2$ & $2.5 \pm 0.2$ & NS & 6.8 \\
\hline & $32-38$ days & $2.3^{\mathrm{abc}} \pm 0.4$ & $2.2^{\mathrm{bc}} \pm 0.4$ & $2.5^{\mathrm{ab}} \pm 0.2$ & $2.1^{c} \pm 0.2$ & $2.5^{\mathrm{ab}} \pm 0.2$ & $2.7^{\mathrm{a}} \pm 0.3$ & * & 11.8 \\
\hline & $32-40$ days & $2.0^{\mathrm{d}} \pm 0.4$ & $2.5^{\mathrm{c}} \pm 0.3$ & $3.1^{\mathrm{ab}} \pm 0.5$ & $2.8^{\mathrm{bc}} \pm 0.6$ & $2.9^{\mathrm{ab}} \pm 0.3$ & $3.3^{\mathrm{a}} \pm 0.6$ & * & 10.2 \\
\hline
\end{tabular}

Means \pm Standard Deviation; ${ }^{*}: \mathrm{P}<0.05,{ }^{* *}: \mathrm{P}<0.01$, NS: Not Significant; Means with the same letter in the same row are not significant $(\mathrm{P}>0.05)$; L.S: Level of Significant; C.V: Coefficient of Variation. 
The present result is in close agreement with that found by Ocak and sivri [24] who restricted broilers to $75 \%$ of ad libitum intake for 10 days of age and found that feed restriction at late age resulted in an increase in the relative weight of edible inner organs than fed ad libitum.

\section{Conclusion}

Feed restriction program seems to affect the live weight, weight gain, carcass weight, and dressing percentage of broiler chicks from 32 - 40 days of age and severe feed restriction regimes lead to weight losses. Therefore, it was concluded that carcass weight of broiler chickens can be controlled using different options of feed restriction programs according to the need of the market, which could help the producer to choose one of the feed restriction programs according to the farm situation and need of market with special consideration to the economic impact.

\section{Acknowledgements}

The authors are highly acknowledgment National Center for Research for providing necessary facilities at various stages of the experiment. The authors are also thankful to the Sudanese Kwaiti Company Farm for their unlimited assistance and co-operation. Also, thankful to the Staff members Environment and Natural Resources and Desertification Research Institute, colleagues and labors of Animal Production Research Department for their assistance and co-operation.

\section{Conflicts of Interest}

The authors declare no conflicts of interest regarding the publication of this paper.

\section{References}

[1] Sahraei, M. (2012) Feed Restriction in Broiler Chicken Production: A Review. Global Veterinarian, 8, 449-458.

[2] Zhan, X.A., Wang, M., Ren, H., Zhao, R.Q., Li, J.X. and Tan, Z.L. (2007) Effect of Early Feed Restriction on Metabolic Programming and Compensatory Growth in Broiler Chickens. Poultry Science, 86, 654-660. https://doi.org/10.1093/ps/86.4.654

[3] Atilgan, A. and Koknaroglu, H. (2006) Cultural Energy Analysis on Broiler Reared in Different Capacity Poultry Houses. Italian Journal of Animal Science, 5, 393-400. https://doi.org/10.4081/ijas.2006.393

[4] Mahmood, S. (2012) Feed Restriction in Broiler Chickens Production: A Review. Global Veterinarian, 8, 449-458.

[5] AOAC (1980) Official Methods for Analysis. 13th Edition, Association of Official Analysis Chemists, Washington.

[6] Gomez, K.A. and Gomez, A.A. (1984) Statistical Procedures for Agricultural Research. 2nd Edition, John Wiley and Sons, Inc., New York.

[7] Lodhi, G.N., Singh, D. and Ichhponani, J.S. (1976) Variation In nutrient Content in Feeding stuff Rich in Protein and Reassessment of Chemical Method for Metabolizable Energy Estimation for Poultry. The Journal of Agricultural Science, 86, 293-303. https://doi.org/10.1017/S0021859600054757 
[8] Azis, A. and Afriani (2017) Effect of Feeding Time Restriction during the Growing Period on Growth Performance of Broiler Chickens. Asian Journal of Poultry Science, 11, 70-74. https://doi.org/10.3923/ajpsaj.2017.70.74

[9] Ismail, W.B. (2007) The Effect of Feed Restriction on Compensatory Growth of Broiler Chicks. M.Sc. Thesis, University of Khartoum, Khartoum.

[10] Saleh, E.A., Watkins, S.E. Waldroup, A.L. and Waldroup, P.W. (2005) Effect of Early Quantitative Feed Restriction on Live Performance and Carcass Composition of Male Broilers Grown for Further Processing. The Journal of Applied Poultry Research, 14, 87-93. https://doi.org/10.1093/japr/14.1.87

[11] Benyi, K., Acheampong-Boateng, O. Norris, D. and Mikasi, M.S. (2008) Effects of Early and Late Skip-a-Day Feeding on the Growth Performance of Male Hybro Broiler Chickens. Asian Journal of Animal and Veterinary Advances, 3, 244-253. https://doi.org/10.3923/ajava.2008.244.253

[12] Yagoub, Y.M. and Babiker, S.A. (2008) Effect of Compensatory Growth on the Performance and Carcass Characteristics of the Broiler Chicks. Pakistan Journal of $\mathrm{Nu}$ trition, 7, 497-499. https://doi.org/10.3923/pjn.2008.497.499

[13] Washburn, K.W. (1990) Effect of Restricted Feeding on Fatness, Efficiency and the Relationship between Fatness and Efficiency in Broilers. Poultry Science, 69, 502-508. https://doi.org/10.3382/ps.0690502

[14] Jones, G.P.D. and Farrell, D.J. (1992) Early-Life Food Restriction of Broiler Chickens 1. Methods of Application Amino Acid Supplementation and the Age at Which Restriction Should Commence. British Poultry Science, 33, 579-587. https://doi.org/10.1080/00071669208417497

[15] Roth, F.X., Kirchgessner, M. and Windisch, M. (1993) Compensatory Growth of Broilers: Effect of Severity, Duration and Onset of Feed Restriction on Performance. Archi-fur-Geflugelkd., 57, 1-8.

[16] Urdaneta-Rincon, M. and Leeson, S. (2002) Quantitative and Qualitative Feed Restriction on Growth Characteristics of Male Broiler Chickens. Poultry Science, 81, 679-688. https://doi.org/10.1093/ps/81.5.679

[17] Boostani, A., Ashayerizadeh, A., Mahmoodian Fard, H.R. and Kamalzadeh, A. (2010) Comparison of the Effects of Several Feed Restriction Periods to Control Ascites on Performance, Carcass Characteristics and Hematological Indices of Broiler Chickens. Brazilian Journal of Poultry Science, 12, 170-177.

https://doi.org/10.1590/S1516-635X2010000300006

[18] Omosebi, D.J., Adeyemi, O.A., Sogunle, M.O., Idowu, O.M.O. and Njoku, C.P. (2014) Effects of Duration and Level of Feed Restriction on Performance and Meat Quality of Broiler Chickens. Archivos de Zootecnia, 63, 611-621. https://doi.org/10.4321/S0004-05922014000400005

[19] Kokoszynski, D and Bernacki, Z. (2008) Comparison of Slaughter Yield and Carcass Tissue Composition in Broiler Chickens of Various Origin. Journal of Central European Agriculture, 9, 11-16.

[20] Janocha, A., Osek, M., Klocek, B., Wasilowska, Z. and Turyk, Z. (2003) Quality Evaluation of Broiler Chickens of Various Genetic Groups. Zeszyty Naukowe Przegladu Hodowlanego, 68, 141-148. (In Polish)

[21] Santoso, U., Tanaka, K. Ohtani, S. and Youn, B.S. (1993) Effect of Early Feed Restriction on Growth Performance and Body Composition in Broilers. Asian-Australasian Journal of Animal Sciences, 6, 401-410. https://doi.org/10.5713/ajas.1993.401

[22] Leeson, S. and Summers, J.D. (2005) Commercial Poultry Nutrition. 3rd Edition, Guelph, Ontario, 257-259. 
[23] Omojola, A.B., Adesehinwa, A.O.K., Madu, H. and Attah, S. (2004) Effect of Sex and Slaughter Weight on Broiler Chicken Carcass. Journal of Food, Agriculture and Environment, 2, 61-63.

[24] Ocak, N. and Sivri, F. (2008) Liver Colourations as Well as Performance and Digestive Tract Characteristics of Broiler May Change as Influenced by Stage and Schedule of Feed Restriction. Journal of Animal Physiology and Animal Nutrition, 92, 546-553. https://doi.org/10.1111/j.1439-0396.2007.00746.x 